\title{
Pure theory and progressive liberalism: Frank Fetter and the Austrian economists
}

DOI:

10.1017/S174413741800036X

\section{Document Version}

Accepted author manuscript

Link to publication record in Manchester Research Explorer

\section{Citation for published version (APA):}

Mccaffrey, M. (2018). Pure theory and progressive liberalism: Frank Fetter and the Austrian economists. Journal of Institutional Economics, 15(3), 469-486. https://doi.org/10.1017/S174413741800036X

\section{Published in:}

Journal of Institutional Economics

\section{Citing this paper}

Please note that where the full-text provided on Manchester Research Explorer is the Author Accepted Manuscript or Proof version this may differ from the final Published version. If citing, it is advised that you check and use the publisher's definitive version.

\section{General rights}

Copyright and moral rights for the publications made accessible in the Research Explorer are retained by the authors and/or other copyright owners and it is a condition of accessing publications that users recognise and abide by the legal requirements associated with these rights.

\section{Takedown policy}

If you believe that this document breaches copyright please refer to the University of Manchester's Takedown Procedures [http://man.ac.uk/04Y6Bo] or contact uml.scholarlycommunications@manchester.ac.uk providing relevant details, so we can investigate your claim.

\section{OPEN ACCESS}




\title{
Pure Theory and Progressive Liberalism: Frank Fetter and the Austrian
}

\section{Economists}

\author{
Matthew McCaffrey \\ University of Manchester \\ Manchester, UK \\ Matthew.mccaffrey@manchester.ac.uk
}

\begin{abstract}
Frank A. Fetter is often classified as an American representative of the Austrian school, yet surprisingly, there is practically no published record of his views of the Austrians or theirs of him, and there is no indication that he ever seriously interacted with them after the First World War. However, Fetter enjoyed many personal and professional relationships with the Austrians, and they shared a reciprocal influence on each other's ideas that deeply influenced their respective research programs. This paper draws on unpublished archival records to explore Fetter's unique place in the history of economics, in particular, his positive and negative interactions with the leading individuals and institutions of the Austrian school. Their half-century of influence sheds light on Fetter and his role in American economics, but also brings to light a wide range of information about the lives, works, and personal relations of the Austrians that have not been included in their biographies or institutional histories.
\end{abstract}

\section{Introduction 1}

Frank Albert Fetter (1863-1949) is often described as a leading representative of the Austrian school in the United States. The similarity between Fetter and the Austrians was observed early in his career (Hoxie, 1905; Whitaker, 1916), and has since become a trope of

\footnotetext{
${ }^{1}$ I would like to thank Sara Goodwin for her tireless efforts with the Fetter archives, material from which appears courtesy of the Lilly Library, Indiana University, Bloomington, Indiana. Karl-Friedrich Israel generously agreed to assist with the translation of the German-language sources. Three anonymous reviewers provided helpful comments on the first draft of the paper.
} 
works studying his ideas (e.g. Dorfman, 1949; Coughlan, 1965; Rothbard, 1977; O’Driscoll, 1980; Herbener, 1999; McCaffrey, 2016). However, despite more than a century of acknowledgement — and apart from a few references to his early writings—none of the research on Fetter actually discusses his personal or professional relationships with the Austrians. Instead, the literature focuses on the doctrinal overlap between their published works. To date, this theoretical common ground has been almost solely responsible for the classification of Fetter's work as a “pecuniary-psychological variant of the Austrian economics" (Dorfman, 1949, 359). Yet historical accounts to justify this claim are almost completely lacking. As a result, Fetter research is broad and speculative, and leaves the impression that his involvement with the Austrians was incidental, or perhaps that he was a 'spiritual' member of the tradition working in isolation from its core members.

This approach and conclusion are understandable, as the published works of Fetter and the Austrians offer scant evidence of any extended influence, or even of contact. There are few citations to Fetter in the principal Austrian works published between the end of the First World War and the 'Austrian revival' of the 1970s, ${ }^{2}$ and almost the only thing that is known is that Fetter befriended Böhm-Bawerk. Certainly, no evidence is presented to indicate that Fetter had any direct involvement with the Austrians after about the time of BöhmBawerk's death. It might seem then that he played no great role within the Vienna school.

However, a large body of hitherto-unknown evidence tells quite a different story. Fetter's unpublished papers, journals, and correspondence reveal a history of close contact with the Austrians spanning several decades, especially during the inter-war period. His personal friends and professional correspondents included many leading Austrians and ‘fellow-travelers,' including Eugen von Böhm-Bawerk, Gottfried Haberler, Henry Hazlitt, W.H. Hutt, Fritz Machlup, Hans Mayer, Carl Menger, Ludwig von Mises, Oskar

\footnotetext{
${ }^{2}$ One exception is Rothbard ([1962] 2009).
} 
Morgenstern, Joseph Schumpeter, and Friedrich von Wieser. The archival records reveal that Fetter was not only actively engaged with the Austrians throughout his career, but that many of them looked to him for theoretical insight, professional advice, and personal friendship.

This paper draws on an extensive collection of archival materials to tell the story of Fetter's relationships with the Austrians. It relies especially on the Fetter papers housed at the Lilly Library at Indiana University. ${ }^{3}$ These materials have not previously been published or quoted. ${ }^{4}$ Yet they provide numerous insights into Fetter's intellectual debts to the Austrians, and theirs to him, not to mention a wide range of fascinating information about the lives, works, and personal relations of leading Austrians that have not been included in biographies or general histories. Fetter's most "Austrian" work was in value and price theory, but his archives include discussions of many topics, ranging from narrow questions of theory to the broader problems of public policy, to the philosophy of liberalism and the hopes for its future. This last point deeply concerned both Fetter and the Austrians. In fact, the decline of liberalism and the rise of monopolistic state planning is a recurring theme that frames many of their conversations. This is natural, given that many of their exchanges took place during the New Deal era, and ran parallel to the growth of planning in Nazi Germany and Soviet Russia.

It is important to state at the outset what this paper does and does not hope to achieve. First, it is not a comprehensive survey of Fetter's economic or political thought, or a critical exegesis of his or the Austrians' published works - these can be found in other literature. Instead, the published works cited below play a supporting role by providing context for the unpublished or unknown materials. Second, this paper does not attempt to decide once and

\footnotetext{
${ }^{3}$ Additional materials are provided from the John Bates Clark and Edwin Seligman papers at Columbia University, the Oskar Morgenstern papers at Duke University, and the Fritz Machlup papers at the Hoover Institution.

${ }^{4}$ The only research to draw seriously on Fetter's papers is Warren Samuels's study of Fetter's involvement in the academic freedom scandal surrounding E.A. Ross's dismissal from Stanford (Samuels, 1985).
} 
for all whether Fetter should be considered a card-carrying member of the Austrian schoolas explained below, there is room for debate about his views, which are nuanced. Instead, this article fills a genuine gap in the history of both American and Austrian economics by taking a closer look at Fetter, who provided a bridge between them.

The paper is organized roughly chronologically: Section II surveys Fetter's early contact with Vienna, especially with Böhm-Bawerk and Schumpeter; Section III discusses Fetter's relations with the younger Austrian school during the inter-war period, and the tributes they paid to each other; Section IV outlines Fetter's views on the decline of liberalism and his discussions with the Austrians about reversing it; Section V examines his account of the Austrian school during his final years, as he reflected on his own place in the development of economic theory; Section VI concludes with suggestions for future research.

\section{First Communications with Vienna}

The period prior to 1914 is usually the only one in which Fetter is thought to have communicated with Vienna, and it therefore serves a useful starting point. Yet even here the historical record is sketchy, and is summed up in the claim that Fetter twice visited Austria and met the leading representatives of the Austrian school (Howard and Kemmerer, 1943). In reality, he formed lasting bonds with several Austrians, and became one of the best-known foreign economists in Vienna.

Fetter's research agenda at the turn of the century involved nothing less than a revision of the entire theory of distribution. In particular, he was interested in rigorously developing the subjectivist, marginalist approach to economic theory and spinning out its various threads to their logical conclusions. As his contemporaries recognized, his approach was fundamentally Mengerian (Hoxie, 1905; Whitaker, 1916). Moreover, revising the theories of capital and interest meant Fetter was obliged to engage Menger's followers as 
well. This he did, starting with a 1900 article on "Recent Discussion of the Capital Concept," published in the Quarterly Journal of Economics (Fetter, 1900). This was the start of a long and serious public engagement with Austrian ideas. Over the course of the next fourteen years, he published the bulk of his many writings on distribution theory that dealt directly or indirectly with Austrian theories, especially Böhm-Bawerk’s (Fetter, 1977).

Given that the Austrians were then flourishing, it is no surprise that Fetter took the time to meet them personally during his visits to Europe in 1910 and 1914. In addition, in 1910 the outlook must have seemed bleak for the German historical tradition in which Fetter had been trained. His personal journal recounts a conversation about the state of German economics with his former doctoral professor, Johannes Conrad (University of Halle). Conrad was pessimistic about the future of German historicism, citing a lack of new research and outstanding young students. In fact, the sentiment in the conversation was generally that the school was on the verge of extinction (Fetter, 1910, 89). Georg Brodnitz ${ }^{5}$ similarly declared that the decline was driven by a lack of large works on German economic history. Brodnitz suggested that the task of writing them should have been undertaken by Gustav Schmoller, but that he lacked the theoretical groundwork and was unable to understand the subject as a whole. In general, Conrad and Brodnitz agreed that both Schmoller and Werner Sombart were brilliant but too radical, and speculated that Eugen von Philippovich would replace Adolph Wagner at the University of Berlin, another hint at the decline of historical work (Fetter, 1910, 89-91). ${ }^{6}$

Fetter's early communications with Austria are thus significant in that they reflect his growing interest in a strand of economic thought that was rapidly outpacing the one in which

\footnotetext{
${ }^{5}$ Brodnitz was an economic historian and student of Conrad at Halle, where he later became professor.

${ }^{6}$ They were mistaken: Wagner and Philippovich both died in 1917, and Sombart took up the Berlin chair. An anonymous reviewer observes, however, that their pessimism was justified by the fact that Philippovich, who had been Menger's student and was then Professor at Vienna, was even being considered for a position at Berlin.
} 
he (and many other Americans) had been trained. His visits also take on added importance because they were among the first personal engagements between Viennese and American economists. Hayek, for instance, states that for many years there was almost no "personal contact or intellectual exchange" between the Austrians and economists in other countries (Hayek, 1992, 32). Immediately prior to the First World War, however, this began to change. Hayek gives John Bates Clark as an example of a notable economist who was in cordial communication (Hayek, 1992, 39).

\section{Eugen von Böhm-Bawerk}

Fetter initiated contact with Böhm-Bawerk in 1903 by sending him a copy of a paper on rent and interest (Böhm-Bawerk, 1903). Then during his first visit to Vienna in 1910, Fetter met Menger, Böhm-Bawerk, and Wieser. ${ }^{7}$ He formed a particularly strong bond with Böhm-Bawerk (Howard and Kemmerer, 1943, 230). They spent time traveling together in the Tirol region of Austria, and exchanged family photographs (Böhm-Bawerk, 1910). Beyond their personal fondness, however, their correspondence reveals a deep professional respect as well.

In particular, Böhm-Bawerk was quick to note their theoretical affinities in areas like price theory. For example, in 1912, Fetter published an article that extensively surveyed existing definitions of price, grouping them into various categories according their emphasis on subjective and objective aspects and their monetary or non-monetary character. $\mathrm{He}$ classified his views and the Austrians' together. Böhm-Bawerk praised both his methods and analysis, declaring that

The method that you follow in [the paper], is Daedalian and original, and has led to a good number of insightful and unexpected results. Moreover, I rejoiced in many a fine

\footnotetext{
${ }^{7}$ It is possible that Fetter met Eugen von Philippovich von Philippsberg at the International Congress of Arts and Sciences in St. Louis in 1904, at which they each read a paper.
} 
use of terms that you incorporated into the analysis of your historical-statistical material. They definitely made a good and important step toward the improvement and standardization of that instrument of our scientific inquiries that we refer to as terminology. (Böhm-Bawerk, 1913)

Their mutual admiration even overcame scientific differences. For example, in 1914, Böhm-Bawerk was preparing the third edition of his History and Critique of Interest Theories when Fetter sent him his recently-published "Interest Theories Old and New" (1914). Fetter believed Böhm-Bawerk's time-preference theory of interest was a major advance in economics, but thought he had erred by retaining productivity as one of its foundations. Fetter argued instead for a "pure" time-preference theory based solely on subjective values. BöhmBawerk acknowledged the criticism, but could not accept it, though he praised Fetter's integrity as a theorist:

Your work is so penetrated by a truly scientific spirit that I always enjoy reading it even if I cannot fully agree. In this case too, some disagreement will remain. I cannot let go of the opinion that also the "technological" fact of the enhanced productivity of roundabout production is one of the determining forces of interest, and accordingly, that if this technological fact did not exist, interest would still exist as a result of the two other causes that I have acknowledged, albeit with far less intensity; and of course the chain of causation is not as claimed in various "productivity theories," but is rather brought about by a value increase of present goods. (Böhm-Bawerk, 1914)

Böhm-Bawerk's death prevented any final rapprochement between their views, but he did make last-minute changes to his manuscript in order to publicly acknowledged Fetter's essay, which he described as "very remarkable" (Böhm-Bawerk, 1959a, 482) and "exceedingly thorough and instructive," even though Fetter occupied "the outermost wing of 
the purely "psychological' interest theorists" and took a "far more extreme" view than himself (Böhm-Bawerk, 1959a, 476). ${ }^{8}$

\section{Joseph Schumpeter}

Fetter's interest in the ideas germinating in Vienna was not limited to the older members of Menger's school, however: he was also fascinated by the work of younger economists. His other significant connection prior to the War was formed in the US when, in 1913, he befriended Joseph Schumpeter while he was an exchange professor at Columbia University. Schumpeter visited Fetter at Princeton and stayed overnight in his home, where his distinctive personality caused a sensation and made a lasting impression on Fetter, his wife Martha, and their young son, Frank Whitson. Schumpeter also lectured to Fetter's students, who no doubt also enjoyed the unique experience (Schumpeter, 1913). The two men later travelled cross-country together to Minneapolis for a meeting of the American Economic Association (Fetter, 1974). ${ }^{9}$

Upon leaving the US in 1914, Schumpeter apologized for not being able to visit Fetter again, and remarked that, "I always felt that in the inspiring company of American colleagues I could turn out much better things than I shall be able to over there [in Europe]" (quoted in Fetter, 1974). But they remained on friendly terms until their last years (e.g. Schumpeter, 1928, undated). For instance, Fetter accepted Richard A. Lester, one of Schumpeter's

\footnotetext{
${ }^{8}$ Böhm-Bawerk bestowed this praise despite having criticized some of Fetter's views on capital theory (BöhmBawerk, 1959c, 57-70). He also described aspects of Fetter's "The Nature of Capital and Income" (1907)—a review of Irving Fisher's work - as "keen and significant” (Böhm-Bawerk, 1959b, 404).

${ }^{9}$ Robert Loring Allen's biography of Schumpeter confuses this chronology: in his account, Schumpeter met Fetter during the trip to the AEA meeting, and later visited Princeton (Allen, 1991, 133-134). But Frank W. Fetter records the Princeton visit as happening before the journey to Minneapolis (Fetter, 1974). His version is confirmed by Schumpeter's correspondence, which only exists in the Fetter archives (Schumpeter, 1913). McCraw (2007) makes a related but understandable error: he claims Edwin Seligman wrote to Fetter to express his irritation with Schumpeter and to warn Fetter against traveling with him. However, Seligman's letter, which describes Schumpeter as a bore, was actually written by Schumpeter, and is only jokingly signed "Seligman." As Fetter explained to his confused family, the name was wordplay: "in German a selig man was a "blessed", "happy" or "tipsy" man"” (Fetter, 1974). This joke would have been quite bizarre, however, if it had been Schumpeter's first communication, as Allen suggests.
} 
University of Bonn pupils, as his graduate student and personal assistant (Lester, 1931). In his turn, Schumpeter honored Fetter by describing him as an important and original theorist who "erected a building that was his own," as opposed to simply following in the tracks of others (Schumpeter, 1954, 874). ${ }^{10}$

During Fetter's Vienna trips, he must have made the acquaintance of other young economists in Böhm-Bawerk's seminar, though his personal diaries do not mention specific names. It is certain, however, that his works were already well-known in Austria, and that they continued to be studied throughout the 1920s. It is less certain though how Fetter's reputation had first spread to Vienna. Hayek suggests that Schumpeter brought the ideas of the American economists back with him from his 1913-1914 trip (1992, 32). However, Fetter's reputation had already been established by this point, as had Schumpeter's in the US. Schumpeter had met Clark in England in 1907 (Schumpeter, 1907b), and through him sent Fetter and Irving Fisher copies of his first book, Das Wesen und der Hauptinhalt der theoretischen Nationalökonomie (Schumpeter, 1908a; 1908c). Schumpeter was keen to impress his international colleagues, whose contributions to theoretical economics (as opposed to German historical work) he admired and wanted to emulate (Schumpeter, 1907a).

Schumpeter undoubtedly regaled his friends with stories of the Americans, but he was not the basis of their reputation in Vienna. ${ }^{11}$ Fetter's international standing seems more due to Böhm-Bawerk, who, for example, encouraged Mises to study the Americans (Mises, 2008, 119). As Salerno (1999) observes, this explanation is the most plausible, as Böhm-Bawerk had already debated Fetter and formed a personal friendship with him several years before Schumpeter's trip abroad. Moreover, Schumpeter read Fetter extensively before meeting him,

\footnotetext{
${ }^{10}$ This was Schumpeter's mature judgment: in 1907, he remarked to John Bates Clark that Fetter was one of several economists "who can be said to belong to what I like to call your school" (Schumpeter, 1907a).

${ }^{11}$ Allen (1991) explains that Schumpeter sought out as many prestigious economists as he could, and was proud of his successful associations with them. Hayek was probably unaware of Fetter's visits to Austria, as he does not mention them in his list of trips to Vienna by foreign economics professors (Hayek, 1992, 33).
} 
as he reviewed his first textbook The Principles of Economics (Fetter, 1905a) for the Zeitschrift für Volkswirtschaft, Sozialpolitik und Verwaltung. Schumpeter's appraisal was quite positive, noting that it "surely deserves special attention, not only as a textbook that is rich in content, but also as a scientific achievement." He went on to explain that Fetter's value theory is "very attractive and clear", and that it will "strike a chord with those of the proponents of the Austrian school. Indeed, Fetter is much closer to the latter than the other American theorists" (Schumpeter, 1908b, 2018). This is consistent with Fetter's own intention for the book, which, as he explained in a letter to Herbert Davenport, was "to give the generally accepted Austrian analysis of marginal utility" (Fetter, 1905b).

\section{The Early Inter-War Period}

Fetter's contact with Europe was severed during the First World War. Despite Austria's political and economic difficulties though, intellectual activity gradually resumed in Vienna following the end of hostilities. In particular, largely due to the efforts of Mises, the Nationalökonomische Gesellschaft ${ }^{12}$ was revived after a long hiatus (Craver, 1986, 17-18). Communication with America also resumed, including with Fetter and other prominent economists. Böhm-Bawerk's wife Paula had written to Fetter in 1916 to send him copies of her late husband's last published works, but the War intervened. In 1919 she wrote again, this time to ask for copies of correspondence between Fetter and Böhm-Bawerk that could be included in a planned full-length biography of her husband. "In between," she wrote, "lies the ghastly war - and now that we have peace again, I turn to those gentlemen whom I can surmise have remained untouched by the madness that has gripped humanity, and, as servants of universal science, are above the strife and hatred of peoples" (Böhm-Bawerk, 1919). ${ }^{13}$

\footnotetext{
${ }^{12}$ Usually rendered as "National Economic Association" or "Vienna Economic Society."

${ }^{13}$ Fetter subsequently paid tribute to Böhm-Bawerk in a 1923 testimony before the Federal Trade Commission, in which he was asked to explain the principle of marginal value as it related to the law of supply and demand. In response, he cited the Austrians and, in particular, Böhm-Bawerk's illustration of marginal utility (inspired by
} 
Another significant event in Austrian-American relations at this time involved Carl Menger, who, though long retired from teaching, was still much admired by the younger economists (Hayek, 1992, 21-22). In 1920, on the occasion of his $80^{\text {th }}$ birthday, the Nationalökonomische Gesellschaft coined a series of medals in his honor. It entrusted James T. Shotwell of Columbia University with several of these to take home with him (Stearns, 1921a), to be distributed "as a tribute from Austrian economists to American economists" (Stearns, 1921b). Besides Shotwell, the intended recipients were Fetter, John Bates Clark, Frank Taussig, Edwin Seligman, J. Laurence Laughlin, Sigmund Zeisler, and Henry Jewitt Furber. Schumpeter said the medals were given on behalf of Menger, Wieser, and the Society, “in token of our cordial feelings of sympathy and admiration" (Schumpeter, 1920).

Fetter thus continued to enjoy the admiration of the Austrians between the Wars. In fact, Hayek notes that during his own time as a student, "the work of the American theorists John Bates Clark, Thomas Nixon Carver, Irving Fisher, Frank Fetter, and Herbert Joseph Davenport was more familiar to us in Vienna than that of any foreign economists except perhaps the Swedes" (Hayek, 1992, 32). ${ }^{14}$ Hayek actually acquired a letter of introduction to Fetter from Schumpeter, although no record of an actual meeting exists (Schumpeter, 1923). Nevertheless, throughout the 1920s, Fetter continued to befriend and assist the Austrians in their work. In 1926, Ludwig von Mises, then an acknowledged leader of the younger generation, visited Fetter at Princeton (Fetter, 1938b). As explained further below, they continued to follow each other's work for many years. Fetter's professional and intellectual support was likewise sought the younger scholars in and around Mises's circle. Gottfried Haberler also met Fetter in America, and also developed a lasting friendship. He eventually

Menger), in which a farmer allocates a supply of grain sacks amongst himself, his family, and his pet parrot (Fetter, 1923c, 18003).

${ }^{14}$ Hayek did, however, obtain an assistantship with Jeremiah Jenks (Hayek, 1992, 35; 1994, 65-66), Fetter's former teacher who had convinced him to study at Halle. 
came to rely on Fetter in his teaching at Harvard, writing that he was in constant need of his papers on value theory for his lectures on welfare economics (Haberler, 1932).

\section{The Wieser Festschrift}

Fetter's status as a key figure in the development of Austrian economics was recognized in 1927 when he was awarded the Karl Menger Medal by the Austrian Economic Society (Howard and Kemmerer, 1943). His reputation was further enhanced in the late 20s through his work on a significant but now-neglected project, namely, a festschrift in honor of Wieser to mark his seventy-fifth birthday. Wieser passed away just a few weeks after this celebration, and only lived to see the first volume of the collection in proofs. But the festschrift was nevertheless an important milestone for the Austrian school and for economics generally. It was eventually published in four volumes between 1927 and 1932 under the title Die Wirtschaftstheorie der Gegenwart, or Economic Theory at Present. ${ }^{15}$ The project was spearheaded by Hans Mayer, Wieser's protégé and a chair at the University of Vienna. Mayer shared editorship of the collection with Fetter and Richard Reisch. ${ }^{16}$

Mayer set to work on the collection in 1925 . He explained his editorial invitation to Fetter on the grounds that "Professor von Wieser would be honored very much if you would accept this invitation for an editorship because he esteems the American economics school so highly and you being one of the most famous writers of it and so well known especially at Vienna" (Mayer, 1925a). The purpose of the collection went beyond simply honoring Wieser as a scholar and teacher, however. As Mayer further explained, "The edition of this book will be of the greatest importance for the two economic Schools of America and Austria wich [sic] are so closely connected" (Mayer, 1925a).

\footnotetext{
${ }^{15}$ Arlene Oost-Zinner's translation of Schulak and Unterköfler (2011) renders the title awkwardly as "The Economic Theory of the Presence," but the translation used here is clearly more in keeping with the original. Fetter rendered it "Present Day Economic Theory."

${ }^{16}$ Reisch was President of the Austrian National Bank and former Austrian Minister for Finance.
} 
Fetter accepted Mayer's offer and began soliciting and editing contributions from prominent American economists. His personal and professional connections were invaluable in this task, and he quickly received the cooperation of Thomas Nixon Carver, Irving Fisher, Frank Knight, and Edwin Seligman. John Bates Clark, J.R. Commons, Richard T. Ely, E.W. Kemmerer, Jacob Viner, and several others soon followed. An honorarium of one hundred gold marks was promised to each contributor (Mayer, 1925b), but in a touching gesture, Fetter declined his payment and instead made it a gift to Paula Böhm-Bawerk, who was also Wieser's sister (Mayer, 1925c).

With Fetter's assistance, American authors were well-represented. Their contributions were integral to Mayer's project, and were intended to accomplish more than simply to showcase the best of Austrian economic thought. As Fetter explained to Edwin Seligman, "It is natural and evident that the Austrian editors hope to show the traces of influence, immediate or remote, that the Austrian school has exerted; but the broader purpose of the work requires the representation of all the clearly articulate trends of thought among us" (Fetter, 1925a). In other words, it was intended to explain some distinctively Austrian contributions, but also those of other schools.

In late 1925, in connection with the festschrift, Fetter made the acquaintance of another young Austrian, Oskar Morgenstern, who was visiting Columbia University on a Rockefeller Foundation scholarship after having completed his $\mathrm{PhD}$. Morgenstern soon began work as Fetter's editorial assistant on the festschrift and as a go-between with Mayer. His proximity to Fetter, as well as his job assisting Mayer with editing the Zeitschrift für Nationalökonomie (Craver, 1986, 17-18), made him a natural choice. He and Fetter worked closely throughout early 1926 to collect, edit, and sometimes translate papers from the American contributors, and Morgenstern himself translated Fetter's chapter on economic thought in America. He stayed as Fetter's guest in Princeton, and a mutual admiration 
developed. Afterward, Fetter followed the younger man's career closely, and his name was briefly touted as a replacement when Fetter retired from a two-year stint at the University of Illinois (e.g. Morgenstern, 1936; Fetter, 1936a; Bogart, 1936). Morgenstern eventually moved to Princeton in 1938 , at which point Fetter was fully retired but still intellectually active.

In any case, the final version of the festschrift was an extraordinary example of international cooperation in economics, uniting eighty-one authors from well over a dozen countries in a series of definitive accounts of the state of the science. The papers examined the major subject areas of economics as well as its development in specific nations (Schulak and Unterköfler, 2011, 110). ${ }^{17}$ Although the publication of the fourth volume was delayed until 1932, ${ }^{18}$ the complete collection was received positively. For example, in the Economic Journal, H.E. Batson described it as "a sort of ecumenical symposium, a majority report of an academic League of Nations" (Batson, 1934, 464). J.R. Commons likewise wrote approvingly of "the editors' purpose of a world economics with national and personal deviations," claiming that the contributions were "the augury of a new nationalism, a new internationalism and a real science of economics" (Commons, 1933, 100).

Fetter's role in the undertaking went beyond editorship: his own chapter, a study of the development of economic thought in America, was itself a tour de force. In fact, Mayer valued it so highly that he waived his own rule on the size of manuscripts (Fetter, 1926a, 1926b), and declared that "There is no doubt that your contribution will be the focus of the work" (Mayer, 1926). Batson called it "masterly" (Batson, 1934, 464), and J.R. Commons likewise referred to it as "a masterful, condensed survey" (Commons, 1933, 100). Morgenstern agreed, and wrote enthusiastically to Fetter that "Here [in Vienna] everybody is charmed by your paper on Economics in America which is said to be the best paper in the

\footnotetext{
${ }^{17}$ Craver's (1986) otherwise thorough account does not mention this international collaboration.

${ }^{18}$ The final published volume was actually Volume II in the sequence.
} 
first volume... I must confess that it gives the best picture of the present situation of American economics I can imagine" (Morgenstern, 1927). He hastened to add though that a Hungarian journal had published a negative review: according to Morgenstern, Othmar Spann had arranged the criticism — written by Theo Suranyi-Unger — as a way to discredit the marginal utility theorists. ${ }^{19}$

Morgenstern remarked that Spann "holds that the marginal theory is dead in America (and everywhere!!) and that the Institutionalists have taken its place. Since he hardly can read English he is very little pleased to read the contrary of his opinions in your paper" (Morgenstern, 1927). He further mentioned that one of Spann's books was about to appear in English, and asked for Fetter to review it so as to expose its "manysided defects"

(Morgenstern, 1927). Fetter did not take up the suggestion. He did, however, promote Morgenstern and his research to other economists well after his own retirement (Fetter, 1941), and referred him to colleagues as "brilliant" (Fetter, 1938d).

Analyzing the full significance of the festschrift requires a separate paper, so I conclude by noting that at this vital moment in the history of the Austrian tradition, Fetter was working diligently to recognize its achievements and support its members, and they were doing the same for him.

\section{The London Connection}

Ironically, at the same time Fetter's reputation among the Austrians was at its peak, his practical influence as a theoretician was beginning to wane (Salerno, 1999). This was due not so much to a lack of interest in his ideas as a lack of resources for studying them; in fact, the younger generation gratefully acknowledged Fetter's achievements. The first edition of

\footnotetext{
${ }^{19}$ Spann's interactions with the Austrians are discussed in Craver (1986). In his early career Suranyi-Unger was a follower of Spann, and also exchanged critical letters with Fetter regarding the history of value theory. He and Fetter became friendly, however, after Suranyi-Unger moved to the United States.
} 
Lionel Robbins' Essay, for instance, included several citations to Fetter alongside references to Menger, Strigl, Hayek, Haberler, and Morgenstern (Robbins, 1932, 15, 61, 63, 102). Robbins also recognized his debt to Fetter's writings on capital and interest (Robbins, 1971, 105), and it is clear he held his contributions in high regard.

A variety of factors contributed to the decay of Fetter's influence as a "pure" theorist. Most importantly, by the late 1920s his earlier works on capital, interest, and rent were in short supply. This was partly due to the limitations of print publishing, which made copying and distributing them difficult, but also to a crowding-out effect created by Fetter's constant work on other topics during the last twenty-five years of his life. The inaccessibility of his papers was especially noted in the 1930s amongst the circle of young economists at the London School of Economics led by Robbins and Hayek. Fetter may have met the members of this group in the summer of 1931, which he spent touring England with his wife and lecturing at various universities.

The London group was impressed, and they approached Fetter several years later to discuss collecting and republishing his most important papers on capital and interest. ${ }^{20}$ Their agent in the negotiations was Fetter's friend and former master's student at Princeton, Noel Frederick Hall. ${ }^{21}$ In 1935, Hall visited Fetter in the United States with a proposal to publish a collection of his articles in London. The suggestion came from Robbins and others in Britain "who owe a good deal to your work" (Hall, 1935a). Fetter agreed, and he and Hall began drawing up the table of contents, which focused on three major strands of research: the general theory of value, the theories of interest and rent, and the theory of population (Fetter,

\footnotetext{
${ }^{20}$ The idea to republish Fetter's writings was raised repeatedly from the 1920 s onward, including by him. It is indicative of his reputation and influence that each of these efforts seems to have been taken up independently, without knowledge of the others. Ultimately, none came to fruition until almost thirty years after his death, in the collection titled Capital, Interest, and Rent: Essays in the Theory of Distribution (1977).

${ }^{21}$ Hall was professor at University College London.
} 
1935b). Hall returned home with a letter from Fetter to the London economists, about which he was sure "Robbins, Hayek + Co. will be delighted" (Hall, 1935b).

A year later, however, Fetter had heard nothing further from Hall, and wrote to inquire about the status of the project (Fetter, 1936b). Hall apologetically explained that he had been overwhelmed with other duties, but that he intended to get back to it immediately. His plan was to give the proposal to another Austrian, Paul Rosenstein-Rodan, who was then advising Allen \& Unwin about their publications, and therefore in a good position to assist (Hall, 1936). Strangely though, at this point all discussion of the project ends, and the planned book never appeared. The exact reason remains unknown, though one explanation is that it was dropped after a personal feud between Robbins and Hall developed in late 1935 (Howson, 2011, 284-287). This is speculative, of course, but it would help to explain why the collection, which had been entrusted to Hall's care, was abandoned, and how it is that he could have found himself in a "stupid, pathological state" about it at the time (Hall, 1936).

\section{The Great Depression and the New Deal}

Fetter's writings from 1900 until the mid-1920s mainly concerned value, price, and distribution theory, and through these topics he enjoyed his greatest influence on the Austrians. However, as a result of his progressive-era training and concern with social welfare, Fetter also developed a fascination with competition and monopoly, especially legal cases of restraint of trade and violations of the Sherman anti-trust laws. In the 1920s, this interest developed into a full-blown research agenda that accounted for most of his academic and public work until his death in 1949.

Monopoly was, for Fetter, the single greatest threat to economic and social harmony in the United States. During the Great Depression especially, Fetter focused on economic policy and the question of if and how monopoly was to be tolerated (and even encouraged) as 
part of the national recovery plan. Throughout, he was a relentless critic of monopoly, big business, and any attempt to fix prices or inhibit competition. He was especially ferocious in his attempts to put an end to price discrimination via the basing point system of delivered prices (Fetter, 1971 [1931]). This work took him away from theory and into the policy and regulatory sectors, and he often consulted or provided testimony for the Federal Trade Commission (in 1923) and the Temporary National Economic Committee (1939 and 1941).

\section{The Fortunes of Progressive Liberalism}

Despite, or perhaps because of Fetter's diminished role as a leader in theory, his work on monopoly and public policy allowed him to engage the Austrians, especially the younger men, in a different way than his earlier writing had. In particular, his later interests offered some common ground between the classical liberalism of many Austrians and Fetter's own progressive liberalism.

Fetter's political views are paradoxical and difficult to classify. On the one hand, he was influenced in his youth by the American progressive economists, especially Richard T. Ely, Edward A. Ross, and John R. Commons. He endorsed, for instance, their general view that economic experts should help guide public administration, thereby limiting the excesses of laissez-faire, as well as some of their specific policy proposals relating to immigration restrictions and eugenics (Fetter, 1913, 1925; Leonard, 2016, 164-165). On the other hand, he was a firm advocate of free trade, free markets, and the power of competition to promote social progress, whose greatest enemies were monopoly and big business. Perhaps unsurprisingly, the labels he used to describe his views shifted frequently, and he referred to himself variously as a progressive, a liberal, and a progressive-liberal, among other things.

Fetter's idiosyncratic politics help to explain why, in the 1930s, his work began to overlap with the interests of the Austrians in a different way. The New Deal, with its large- 
scale expansion of government regulatory power-especially in relation to price policiesrepresented a marriage between big business and big government that posed a serious threat to the liberal ideals of free trade and competition. The uncertain future of private enterprise, combined with sweeping reforms intended to protect domestic industry and maintain high prices, provided ample fodder for those liberals who were keen to warn against the dangers of fascist or socialist policies. Fetter and the Austrians were united in this apprehension, and shared their anxieties with each other.

\section{W.H. Hutt}

Of all economists associated with the Austrian tradition, the one who was in this period closest to Fetter in his general outlook was W.H. Hutt. ${ }^{22}$ Like his contemporaries, Hutt found that his work was "closely indebted" to Fetter's writings (Hutt, 1937). In particular, Hutt was also a critic of monopoly power, especially in labor markets or when exercised through labor unions. In the mid-1930s, he was also concerned with economists' roles as policy advisors and molders of public opinion. He outlined his position most fully in his 1936 book Economists and the Public, a copy of which he sent to Fetter. ${ }^{23}$

Fetter proved a kindred spirit, writing to Hutt that, "I wish to express my great enjoyment and cordial agreement at almost every point with your keen and penetrating analysis." According to Fetter, Hutt's book was “a much needed expression of the spirit and philosophy of the Liberal Economists which is being forgotten in the midst of the clamors from the extremist camps of Communism and Fascism" (Fetter, 1937). They agreed

\footnotetext{
${ }^{22}$ An anonymous reviewer observes that Hutt engaged with and produced Austrian works only after WWII. Nevertheless, he is worth including here as an example of an economist who was influenced first by Fetter and then by the Austrians, the opposite of the typical case as studied in this paper.

${ }^{23}$ Coincidentally, a decade earlier Fetter had written an address with the same title, and on the same topic (Fetter, 1925b). In their letters, Hutt hastened to clarify that he had not intentionally duplicated the title, but rather believed he must have read the address at the time and "unconsciously absorbed its ideas." In fact, according to Hutt, his own title was originally to be Competition and Opinion, but he adopted the alternate version on Hayek's advice (Hutt, 1937). The original became the subtitle.
} 
particularly that the maintenance of economic freedom required restricting private monopoly and preventing combinations that endangered consumer sovereignty (Hutt, 1936, 126-127, 190, 271-272). Unfortunately, any efforts in that direction were being hindered by interest groups, usually businesses, but also by economists biased in favor of business (Hutt, 1936, 34, 56-57, 227, 231-232).

Fetter quoted Hutt to this effect in one of his unpublished speeches titled, "Can Capitalism Survive?" (Fetter, 1935a). It is the clearest and most concise statement of Fetter's economic attitudes of this period, and he described it as a "statement of the philosophy of the Progressive Liberal Economists in American [sic] in the best traditional sense of the now much abused term "Liberal"”' (Fetter, 1937). Its central message was that American capitalism — which had only ever been imperfectly realized — had gradually been transformed into a system of "corporationism." Supported by special privileges and governmental refusal to enforce the anti-trust laws, large businesses were free to act as monopolists, and wealth and ownership were being concentrated in an increasingly small number of hands. For Fetter this meant a march toward fascism and economic control, and his only solution was a return to the rule of the anti-trust laws, which he held to be consistent with liberalism (Fetter, 1935a).

Hutt argued along similar lines in the passage Fetter quoted, which includes Hutt's usual emphasis on the importance of maintaining competitive institutions (Hutt, 1935). Fetter departed from Hutt mainly in regard to the practical question of how to dismantle existing monopolies: Hutt recommended compensating them for their losses, a policy Fetter emphatically rejected. In his view, monopolies in the US existed largely in blatant violation of anti-trust law, and deserved no compensation for the loss of illegal gains (Fetter, 1937). 


\section{Ludwig von Mises}

Fetter's unique relationship to the Austrians is also seen through his relationship with Mises. As far as their approaches to economic theory were concerned, the two men were close. Politically, however, there were tensions between Mises's classical liberalism and Fetter's progressive liberalism. Their most important common ground in economic theory concerned Fetter's development of the pure time preference theory of interest, which Mises occasionally noted was similar to his own (Mises, 2008, 124). Mises's debt to Fetter is stronger than his published work indicates, however. In 1938, while drafting Nationalökonomie, the German-language predecessor to his book Human Action, Mises told Fetter candidly that, "In these last months I have reread your contributions on the theory of interest. It is my firm opinion that they are more important than any other contribution on the subject since Böhm-Bawerk. I am indebted to them” (Mises, 1938). Mises’s admiration for Böhm-Bawerk only underscores the importance of his evaluation of Fetter.

For his part, Fetter may have absorbed ideas about business cycles from Mises. O'Driscoll (1980), for example, shows the similarities between their views, especially as outlined in Fetter's paper "Interest Theory and Price Movements" (Fetter, 1927). Yet O'Driscoll also observes there is no published evidence Fetter was familiar with Mises's work on cycles. However, unpublished correspondence reveals that Mises visited Fetter in mid-1926, just a few months before Fetter presented his paper to the American Economic Association (Fetter, 1938b). Given Mises's emphasis at the time on business cycle research, it is unlikely he would have failed to mention the subject. ${ }^{24}$

\footnotetext{
${ }^{24}$ In the 1940s, Fetter took a strong stand against inflationary monetary policy, which again brought him in line with Mises's views (e.g. Fetter, 1946). This was noted by Norman Lombard, executive secretary of the National Monetary Association, who tried to organize roundtable dinners where monetary experts could debate. Invited guests included Fetter, Mises, Henry Hazlitt, and F.A. Harper (Fetter, 1948).
} 
Political events did more to bring Fetter and Mises into contact than pure theory, however. By the late 30s they had been out of communication for more than a decade, but Fetter had received updates on events in Vienna through people like Morgenstern, who provided him with an insider's account of Mises and the other liberals' fight against foreign exchange control in Austria (Fetter, 1938d). Fetter was inspired to make contact once again after reading Mises's introduction to A.S.J. Baster's The Twilight of American Capitalism: An Economic Interpretation of the New Deal (Mises, 1937). Fetter's interest was further enhanced by Henry Hazlitt's New York Times book review of the English translation of Mises's Socialism, a copy of which Fetter sent to Mises in Geneva. Mises was delighted, though he showed no sign of being familiar with Hazlitt. Interestingly, Hazlitt was at about the same time also writing to Mises to introduce himself and to share the review (Hazlitt, 1984). Given that Hazlitt's article appeared on January $9^{\text {th }}$ and Fetter's letter is dated the $15^{\text {th }}$, Fetter may have been the first person to make Mises aware of Hazlitt, if only by a few days or weeks. In any case, Fetter was happy to find a likeminded economist who shared his skepticism of economic planning, and he confided to Baster that he was looking forward to reading Socialism in full (Fetter, 1938a).

Yet while the growing spirits of nationalism and socialism disturbed both men, they did not agree on all aspects of the best solution to them. Their differences were especially pronounced when it came to the question of immigration. Mises argued repeatedly that economic nationalism led naturally to widespread restrictions in labor markets, particularly on emigration and immigration. These in turn threatened the international economic order and worked against the principles of liberalism. Public policies designed to prevent the free movement of labor were thus for him a non-starter.

Mises made his case forcefully in a 1938 essay, "The Disintegration of the International Division of Labor," a summary of his thinking on the importance of peace and 
free trade (Mises, 1990). He sent it to Fetter in reply to the "Can Capitalism Survive?" speech. Fetter described Mises's argument as "admirable," and even stated that "Nowhere is the case put more clearly" (Fetter, 1938c). But he disagreed on the question of immigration. Fetter had been influenced early on by Malthus, ${ }^{25}$ whose population theory he had criticized but ultimately accepted (Fetter, 1898). And as President of the AEA, he had stated that immigration would cause a resource crisis in the US if left unchecked (Fetter, 1913). He advanced much the same view to Mises:

I am sure that if you would come here and look at the matter from the standpoint of our American civilization you would concede that your implied proposal to admit the Chinese and East Indians as well as all other people with lower standards of living into this country would mean the complete breakdown of our social as well as political and economic conditions. As a student of Malthus I learned what is perhaps his most certain proposition that immigration from an over-populated country never served to raise the standard of wages there but merely to reduce the wages in the countries with higher standards. A policy of unrestricted immigration means letting the countries of the lowest standards anywhere in the world reduce to their own level the standards of all other countries. (Fetter, 1938c)

Mises sharply disagreed: in his view, differences in productivity, and therefore in wages rates, were the primary factors influencing migration, and only the free movement of labor and capital could equalize wages rates and produce higher standards of living in relatively overpopulated countries. Immigration restrictions were largely a tool of trade union policy designed to keep domestic wage rates artificially high at the expense of foreign workers (Mises, 1978, 1990).

\footnotetext{
${ }^{25}$ Fetter's interest in immigration inspired him to write his $\mathrm{PhD}$ thesis on the Malthusian population problem (Fetter, 1893, 1894).
} 
Disagreement did not diminish their mutual respect though. In 1945, Fetter reviewed Mises's book Bureaucracy in the American Economic Review, likely at the request of Fritz Machlup, who was then acting as managing editor (Fetter, 1945a; Machlup, 1945a). ${ }^{26}$ It was to be the final book review of Fetter's career. Although brief, it offered a broad reflection on the achievements of the older and younger Austrian schools, and of Fetter's admiration for them. He recalled the contrast between the German historicists and the Austrians, observing that "The one pointed the way to the totalitarian state, and the other to a greater and better liberalism in economic and political affairs" (Fetter 1945a, 445). He also drew attention to Mises and Hayek as effective critics of socialism and defenders of free enterprise, and remarked of Bureaucracy that, "the case for free enterprise versus socialism has nowhere been more ably and readably stated in brief compass" (Fetter, 1945a, 446). He concluded by stating that "Professor von Mises is a consummate general theorist" (Fetter, 1945a, 446). Such praise is rare in Fetter's writing, and is usually reserved for economists who deeply influenced him, such as John Bates Clark.

Fetter's “unpretentious" book review (Fetter, 1945b) prompted a fan latter from F.A. Harper of Cornell, who praised its range as well as Fetter's refusal to use jargon. Harper became a major figure in the revival of Austrian economics in the US, especially through founding of the Institute for Humane Studies, which encouraged much of the work done by young Austrians in the 1970s (Blundell, 2014). IHS also played a large part in rehabilitating Fetter's work through the publication of a collection of his papers on capital, interest, and rent (Fetter, 1977).

Machlup shared Harper's enthusiasm, adding that, "I have always been a Fetter fan myself” (Machlup, 1945b). In fact, Fetter's and Machlup's professional interests were

\footnotetext{
${ }^{26}$ Machlup also taught at Princeton, though not at this time.
} 
remarkably similar; both were fascinated with economic terminology and semantics, ${ }^{27}$ and more important for Fetter, Machlup published extensively on monopoly and also wrote a book devoted to the basing-point system of delivered prices (Machlup, 1949). It cited Fetter heavily and positively, the last major project by an Austrian to do so in his lifetime.

Unfortunately, it appeared just one month before his death in March 1949, and he never had the chance to read it (Mund, 1949). Several months later, in September, Mises published Human Action, which drew significantly on Fetter's work, particularly his theories of capital and interest (Mises, 1998 [1949]). It was Mises’s writing that eventually drew renewed attention to Fetter during the "Austrian revival" of the 1960s and 70s.

\section{Final Years}

This paper has so far focused on Fetter's direct interactions with the Austrians. Naturally, however, he also expressed opinions about their work in other contexts. These are worth noting for the sake of completeness, but also because they provide a useful way to summarize Fetter's place in relation to their ideas. The later years of his career in particular provided ample opportunity for Fetter to reflect on his place in the history of economics relative to established figures and schools of thought. This he did repeatedly in the 1920s, 30s, and 40s. For example, in the early 20 s he produced a series of articles on the history of economic theory that involved a great deal of comparative study of ideas, thinkers, and schools. Moreover, these papers positioned him ideally to comment on the importance of different strands of economic thought. They consisted of two two-part articles, the first set dealing with the question of what should be the central theme of economics (Fetter, 1920a, 1920b), and the second with the history of value theory (Fetter, 1923a, 1923b). Throughout these arguments Fetter drew on and praised the Austrians, especially Böhm-Bawerk and

\footnotetext{
${ }^{27}$ Fetter published many articles on economic terminology, and planned to write an extensive history of the subject, a project that was never completed.
} 
Wieser, who he credited with major roles in defining the proper scope of economics, and with eliminating classical errors.

However, as he made clear in his debates with Böhm-Bawerk, Fetter was also a critic, and he was uncomfortable with being pigeonholed as a member of a school. His own position was one of methodological tolerance. He believed that theoretical, historical, and institutional studies could all serve valuable purposes in economics, so long as they remained grounded in the real world. The true danger was misusing a method by taking it to extremes. Fetter explained his position in a letter to Richard T. Ely:

You know that my training was primarily in the narrow historical field under Jenks and Conrad although I never have been able to get any other economist to think of me in that light, for I became at once tagged in my youthful days because of some early theoretical articles with the brand of abstract Clarkian and Austrian economists. As a matter of fact I am fundamentally interested always in the historical approach and never have had real sympathy with the a priori deductive treatment of economics when it is completely severed from observation and historical studies. However, the extreme of reading the logical or formative method out of economic practice seems to me to be abstract and untenable. (Fetter, 1931; second emphasis added)

In other words, theory should be both logically sound and realistic, and should be wary of the opposing dangers of pure historicism or overly-abstract theory. Fetter's comments at first imply he was critical of Austrian methods on the grounds that they were too abstract, but his position is more nuanced (Herbener, 1999, 128-129). For example, he explicitly defended Menger, Böhm-Bawerk, and the early marginal utility theorists from the 
claim that they were armchair philosophers lacking practical experience (Fetter, 1923a, 595$596) .^{28}$

Fetter expanded on his opinions in the mid-1940s in one of his last (and unpublished) manuscripts, an extensive survey of the development of economic theory from classical economics to the neoclassical era. Here he complained that labeling economists as members of a school too often served as a convenient excuse to misrepresent their opinions. In his own case, he explained,

[A]ltho my years of economic study were spent entirely under teachers of the historical school, yet I was early tagged as an adherent of "the Austrian school", because of my recognition of their substantial contributions. Soon afterward, for the same reason, I was generally classified as a disciple of John Bates Clark, and that disposed of the matter for a time. Meanwhile, I was vigorously dissenting from some of the views of both. Later the Austrian label was again more frequently applied to me, alternating with "neo-classical", after that term had taken on a more confused meaning. I have even been called an "institutionalist" - a title which I would gladly accept if allowed to define it as I think it should be. I have never been consciously an adherent of any "school" or sect of economic theory and have earnestly striven to prevent either pride of personal opinion or a mistaken sense of loyalty to the ideas of any writer or school from dimming my eyes to newly discovered truth. I have continued to believe that sharp differences of opinions among economists on intellectual issues is consistent with mutual respect and halting friendship, and that in such matters the one loyalty, is loyalty to the search for truth, not to some theoretical hero, living or dead, or to some cult, past or present. (Fetter, unpublished a, 8-9)

\footnotetext{
${ }^{28}$ Among the Austrians, Mises tends to be accused most often of excessive a priorism. However, Fetter's remarks above are unlikely to refer to Mises, as they predate his major works on methodology.
} 
In this account Fetter defines membership in a school as unquestioning devotion to orthodoxy, making it impossible to be both a disciple and a constructive critic. By his own narrow view then, he did not belong to any school, but then again, neither did most economists of his time. In fact, in making these comments, Fetter likely had in mind the classical era, especially some of Ricardo's more dedicated followers, whose devotion he criticized in an unpublished essay from the 1940s titled, "The Ricardian Cult" (Fetter, unpublished b).

Fetter's view of his own work is brought out well by Joseph Dorfman, who categorized it as a "pecuniary-psychological variant of the Austrian economics" (Dorfman, 1949, 359). By this he meant, respectively, that it focused on practical business affairs and relied on modern psychology as its basis rather than the older hedonistic calculus (Dorfman, 1949, 360-365). This formulation is largely based on Fetter's letters and conversations with Dorfman, who approached Fetter to ask about his background while drafting The Economic Mind in American Civilization. Fetter was at first skeptical: he complained that his early critics had failed to read his work seriously and therefore to assess it fairly. While he did not doubt the quality of Dorfman's scholarship, he believed that "as a disciple of Veblen you can not do other than condemn a good part of what I have written, the more so to the degree that you fully understand what I was driving at" (Fetter, 1940). Dorfman quipped in return that "disciple of Veblen" was a contradiction in terms (Dorfman, 1941). Fetter pointed in particular to his Wieser festschrift article as a contribution Dorfman would likely disagree with, because a good part of it was devoted to Veblen and the institutionalists.

Nevertheless, Fetter explained that his theory of capital - as summarized in the Encyclopedia of the Social Sciences — was “in essential harmony with Sombart's institutional treatment of Capitalism" (Fetter, 1940). His exact meaning is unclear, but he could be referring to the idea that capital embodies important historical and institutional traits. In any 
case, Fetter clearly thought it important to point out the compatibility of his views and those of other "schools," rather than their differences. Geoffrey Hodgson likewise observes that Fetter's capital theory bridges several economic traditions by synthesizing elements of German historical, Austrian, and institutionalist views (Hodgson, 2008).

\section{Conclusion}

This paper has surveyed the long history of Frank Fetter's involvement with the Austrian economists, filling a gap that has remained open for several decades. Although I do not take sides on the question of whether Fetter should be included in one specific school of thought, it is clear that his life and work were closely intertwined with the Austrians', and with the fortunes of the Mengerian tradition. At the very least, it should be clear, given their connections, that no history of the Austrian school can be complete without an account of Fetter's involvement, as he was a persistent influence among the people and institutions that shaped Austrian economics in the $20^{\text {th }}$ century. Yet most of their history has been preserved only in Fetter's unpublished papers, and has remained unknown.

However, documenting Fetter's relationship with the Austrians is only a first step in a larger research program that revolves around his life and ideas. As Hodgson (2008) and McCaffrey (2016) both argue, Fetter's work remains topical. And as indicated throughout, there is still ample room for studying his unique place in the history of economics and for applying his ideas to current controversies. There are many areas that stand out as particularly promising for future work. These include Fetter's:

(1) unique mixture of intellectual influences, including his progressive-era political and policy views, all of which can shed new light on debates about the history of American economics (e.g. Hodgson, 2008; Leonard, 2016; Magness, 2018); 
(2) work on the Wieser festschrift, a neglected but highly significant part of the history and legacy of the Austrian school around the world, and its relation to other schools of thought (e.g. Salerno, 1999; Boettke, Coyne, and Newman, 2016;

Wasserman, 2016);

(3) theoretical and applied work on monopoly, and its overlap and conflict with Austrian theory and laissez-faire economic policy (e.g. Salerno, 2004);

(4) research on capital, interest, rent, entrepreneurship (e.g. Hodgson, 2008; Foss and Klein, 2012, 48-50; McCaffrey, 2016);

(5) distribution theory and its application to research on firms and organizations (e.g. Lewin and Phelan, 1999);

(6) distribution theory and its application to research on business cycles and financial crises (e.g. O’Driscoll, 1980, Herbener, 1999, 133-135).

These and many other topics remain open to investigation, and each provides ample reason to reconsider Fetter's work. 


\section{Archives}

Frank A. Fetter mss., 1875-1988. Lilly Library, Indiana University Bloomington. (FAF)

John Bates Clark papers, 1848-1955. Rare Book \& Manuscript Library, Columbia University. (JBC)

Fritz Machlup papers, 1911-1983. Hoover Institution Archives. (FM)

Oskar Morgenstern Papers. Rubenstein Library, Duke University. (OM)

Edwin Seligman papers, 1861-1939. Rare Book \& Manuscript Library, Columbia University. (ES)

\section{References}

Allen, R.A. 1991. Opening Doors: The Life and Work of Joseph Schumpeter, Volume I: Europe. New Brunswick, NJ: Transaction.

Batson, H.E. 1934. "Review of Die Wirtschaftstheorie der Gegenwart." The Economic Journal. 44 (175): 463-470.

Blundell, J. 2014. "IHS and the Rebirth of Austrian Economics: Some Reflections on 1974-1976." Quarterly Journal of Austrian Economics. 17 (1): 92-107.

Boettke, P.J., Coyne, C.J., and Newman, P. 2016. "The History of a Tradition: Austrian Economics from 1871 to 2016." Research in the History of Economic Thought and Methodology. 34: $199-243$

Bogart, E.L. 1936. Letter to Frank A. Fetter, dated 18 April. FAF, Box 7, Folder: Correspondence 1933-1936.

Böhm-Bawerk, E. von. 1959a. History and Critique of Interest Theories. Trans. George D. Huncke and Hans F. Sennholz. South Holland, Ill: Libertarian Press. 
Böhm-Bawerk, E. von. 1959b. Positive Theory of Capital. Trans. George D. Huncke and Hans F.

Sennholz. South Holland, Ill: Libertarian Press.

Böhm-Bawerk, E. von. 1959c. Further Essays on Capital and Interest. Trans. George D. Huncke and Hans F. Sennholz. South Holland, Ill: Libertarian Press.

Böhm-Bawerk, E. von. 1914. Letter to Frank A. Fetter, dated 9 May. FAF, Box 7, Folder:

Correspondence 1913-1914.

Böhm-Bawerk, E. von. 1913. Letter to Frank A. Fetter, dated 29 March. FAF, Box 7, Folder:

Correspondence 1913-1914.

Böhm-Bawerk, E. von. 1910. Letter to Frank A. Fetter, dated 13 December. FAF, Box 7, Folder:

Correspondence 1910-1912.

Böhm-Bawerk, E. von. 1903. Letter to Frank A. Fetter, dated 3 December. FAF, Box 7, Folder:

Correspondence 1900-1904.

Böhm-Bawerk, P. 1919. Letter to Frank A. Fetter, dated November. FAF, Box 7, Folder:

Correspondence 1915-1919.

Commons, J.R. 1933. "Review of Die Wirtschaftstheorie der Gegenwart.” American Economic Review. 23 (1): 99-100.

Coughlan, J.A. 1965. The Contributions of Frank Albert Fetter (1863-1949) to the Development of Economic Theory. PhD Dissertation, Catholic University of America.

Craver, E. 1986. "The Emigration of the Austrian Economists.” History of Political Economy. 18 (1): 1-32. 
Dorfman, J. 1949. The Economic Mind in American Civilization: Volume III: 1865-1918. New York:

Viking.

Dorfman, J. 1941. Letter to Frank A. Fetter, dated 5 January. FAF, Box 3, Folder: Correspondence 1941 Jan.-June.

Fetter, F.A. 1977. Capital, Interest, and Rent: Essays in the Theory of Distribution. Ed. Murray N.

Rothbard. Menlo Park, CA: Institute for Humane Studies.

Fetter, F.A. 1971 [1931]. The Masquerade of Monopoly. New York: Augustus M. Kelley.

Fetter, F.A. 1948. Letter to Norman Lombard, dated 2 February. FAF, Box 3, Folder: Correspondence 1948, Jan.-Mar.

Fetter, F.A. 1946. “Too Much Money.” Saturday Evening Post. 219 (13 July): 124.

Fetter, F.A. 1945a. "Review of Bureaucracy, by Ludwig von Mises.” American Economic Review. 35 (3): 445-46.

Fetter, F.A. 1945b. Letter to Fritz Machlup, dated 9 August. FM, Box 037, Folder: 83037.

Fetter, F.A. 1941. Letter to Ernest L. Bogart, dated 3 November. FAF, Box 3, Folder: Correspondence 1941, July-Dec.

Fetter, F.A. 1940. Letter to Joseph Dorfman, dated 30 December. FAF, Box 3, Folder: Correspondence 1940, Apr.-Dec.

Fetter, F.A. 1938a. Letter to A.S.J. Baster, dated 15 January. FAF, Box 2, Folder: Correspondence 1938 Jan.-June. 
Fetter, F.A. 1938b. Letter to Ludwig von Mises, dated 15 January. FAF, Box 2, Folder:

Correspondence 1938 Jan.-June.

Fetter, F.A. 1938c. Letter to Ludwig von Mises, dated 16 March. FAF, Box 2, Folder:

Correspondence 1938 Jan.-June.

Fetter, F.A. 1938d. Letter to Allen T. Bonnell, dated 5 July. FAF, Box 2, Folder: Correspondence 1938 Apr.-July.

Fetter, F.A. 1937. Letter to William H. Hutt, dated 12 June. FAF, Box 2, Folder: Correspondence 1937, July-Sept.

Fetter, F.A. 1936a. Letter to Oskar Morgenstern, dated 13 January. FAF, Box 2, Folder:

Correspondence 1936, Jan.-July.

Fetter, F.A. 1936b. Letter to Noel F. Hall, dated 23 September. FAF, Box 2, Folder: Correspondence 1936, Aug.-Dec.

Fetter, F.A. 1935a. Unpublished address, “Can Capitalism Survive?” FAF, Box 2, Folder: Correspondence 1935.

Fetter, F.A. 1935b. Letter to Noel F. Hall, dated 4 June. FAF, Box 2, Folder: Correspondence 1936, Aug.-Dec.

Fetter, F.A. 1931. Letter to Richard T. Ely, dated 12 March. FAF, Box 1, Folder: Correspondence 1931, Jan.-June.

Fetter, F.A. 1927. "Interest Theory and Price Movements." American Economic Review. 17 (1): 62105. 
Fetter, F.A. 1926a. Letter to Hans Mayer, dated 16 January. OM, Box 1, 1025-1926, A-G.

Fetter, F.A. 1926b. Letter to Hans Mayer, dated 23 January. OM, Box 1, 1025-1926, A-G.

Fetter, F.A. 1925a. Letter to Edwin Seligman, dated $12^{\text {th }}$ October. ES, Columbia University, Box C10.

Fetter, F.A. 1925b. "The Economists and the Public.” American Economic Review. 15 (1): 13-26.

Fetter, F.A. 1923a. "Value and the Larger Economics, I: Rise of the Marginal Doctrine." Journal of Political Economy. 31 (5): 587-605.

Fetter, F.A. 1923b. "Value and the Larger Economics, II: Value Giving Way to Welfare." Journal of Political Economy. 31 (6), 790-803.

Fetter, F.A. 1923c. "Testimony on basing-point pricing before the Federal Trade Commission on December 11, 1923." United States of America before the Federal Trade Commission. Docket 760: Federal Trade Commission vs. United States Steel Corporation et al., Volume 2, 175-77; 191-217, 779-811.

Fetter, F.A. 1920a. "Price Economics versus Welfare Economics," American Economic Review. 10 (3): 467-87.

Fetter, F.A., 1920b. "Price Economics versus Welfare Economics: Contemporary Opinion.” American Economic Review. 10 (4): 719-737.

Fetter, F.A. 1914. “Interest Theories, Old and New.” American Economic Review. 4 (1): 68-92.

Fetter, F.A. 1913. "Population or Prosperity: Annual Address of the President." American Economic Review. 3(1): 5-19. 
Fetter, F.A. 1910. Unpublished journal “Germany Trip 1910 Note Book.” FAF, Box 6, Folder:

Journals and Diaries.

Fetter, F.A. 1907. "The Nature of Capital and Income." Journal of Political Economy. 15 (3): 129-

148.

Fetter, F.A. 1905a. The Principles of Economics, with Applications to Practical Problems. New York:

The Century Co.

Fetter, F.A. 1905b. Letter to Herbert J. Davenport, dated 2 December. FAF, Box 7, Folder:

Correspondence, 1905-1906.

Fetter, F.A. 1900. "Recent Discussion of the Capital Concept." Quarterly Journal of Economics. 15

(1): $1-45$.

Fetter, F.A. 1898. “The Essay on Malthus: A Centennial Review.” Yale Review. 7: 153-67.

Fetter, F.A. 1894. Versuch einer Bevolkerungslehre ausgehend von einer Kritik des Malthus 'schen Bevolkerungsprincips. Jena: Gustav Fischer.

Fetter, F.A. 1893. Letter to Ellen Fetter, dated 5 March. FAF, Box 6, Folder: Transcription of F.A.

Fetter Letters to his mother, July $3^{\text {rd }} 1892-$ July $12^{\text {th }} 1894$.

Fetter, F.A. Unpublished, a. Unpublished manuscript "The Development of Economic Theory." FAF,

Box 12, Folder: Research and Writings, Drafts, Book, Development of Economic Theory, Ch.

$1-8$.

Fetter, F.A. Unpublished, b. Unpublished manuscript “The Ricardian Cult." FAF, Box 11, Folder:

Research and Writings, Drafts, The Ricardian Cult. 
Fetter, F.W. 1974. “An Early Memory of Joseph Schumpeter.” History of Political Economy 6, 1: $92-$ 94.

Foss, N.J., and P.G. Klein. 2012. Organizing Entrepreneurial Judgment: A New Approach to the Firm. Cambridge: Cambridge University Press.

Haberler, G. 1932. Letter to Frank A. Fetter, dated 12 February. FAF, Box 1, Folder: Correspondence 1932, Jan.-May.

Hall, N.F. 1936. Letter to Frank A. Fetter, dated 16 October. FAF, Box 2, Folder: Correspondence 1936, Aug.-Dec.

Hall, N.F. 1935a. Letter to Frank A. Fetter, dated April. FAF, Box 2, Folder: Correspondence 1935.

Hall, N.F. 1935b. Letter to Frank A. Fetter, dated 10 June. FAF, Box 2, Folder: Correspondence 1935.

Hayek, F.A. 1994. Hayek on Hayek: An Autobiographical Dialogue. Chicago: University of Chicago Press.

Hayek, F.A. 1992. "The Economics of the 1920s as Seen from Vienna." In The Collected Works of F.A. Hayek, Volume 4: The Fortunes of Liberalism. Ed. Peter G. Klein. Indianapolis, In: Liberty Fund, 19-41.

Hazlitt, H. 1984. “An Interview with Henry Hazlitt.” Austrian Economics Newsletter. 5 (1): 1-4, 6.

Herbener, J.M. 1999. "Frank A. Fetter: A Forgotten Giant.” In 15 Great Austrian Economists, ed. Randall G. Holcombe. Auburn, AL: Ludwig von Mises Institute, 123-141.

Hodgson, G.M. 2008. “Editorial introduction to 'Capital' by Frank A. Fetter.” Journal of Institutional Economics. 4 (1): 127-37. 
Howard, S.E., and E.W. Kemmerer. 1943. "Frank Albert Fetter: A Birthday Note.” American Economic Review. 33 (1): 230-235.

Howson, S. 2011. Lionel Robbins. Cambridge: Cambridge University Press.

Hoxie, R.F. 1905. “Fetter's Theory of Value.” Quarterly Journal of Economics 19, 2: 210-230.

Hutt, W.H. 1937. Letter to Frank A. Fetter, dated 30 July. FAF, Box 2, Folder: Correspondence 1937, July-Sept.

Hutt, W.H. 1936. Economist and the Public: A Study of Competition and Opinion. London: Jonathan Cape.

Hutt, W.H. 1935. "Natural and Contrived Scarcities." South African Journal of Economics. 3 (3): 345353.

Leonard, T.C. 2016. Illiberal Reformers: Race, Eugenics, and American Economics in the Progressive Era. Princeton, NJ: Princeton University Press.

Lester, R.A. 1931. Letter to Frank A. Fetter, dated 21 April. FAF, Box 1, Folder: Correspondence 1931, Jan.-June.

Lewin, P., and Phelan, S.E. 1999. "Firms, Strategies, and Resources: Contributions from Austrian Economics." Quarterly Journal of Austrian Economics. 2 (2): 3-18.

Machlup, F. 1949. The Basing-point System: An Economic Analysis of a Controversial Pricing Practice. Philadelphia: Blackiston.

Machlup, F. 1945a. Letter to Frank A. Fetter, dated 2 August. FAF, Box 3, Folder: Correspondence, 1945. 
Machlup, F. 1945b. Letter to Frank A. Fetter, dated 30 August. FAF, Box 3, Folder: Correspondence, 1945.

Magness, P.W. 2018. "The Progressive Legacy Rolls On: A Critique of Steinbaum and Weisberger on Illiberal Reformers.” Econ Journal Watch. 15 (1): 20-34.

Mayer, H. 1925a. Letter to Frank A. Fetter, undated. OM, Box 3.

Mayer, H. 1925b. Letter to Arthur Lyon Bowley, dated 12 December. OM, Box 2.

Mayer, H. 1925c. Letter to Frank A. Fetter, dated 23 December. OM, Box 2.

Mayer, H. 1926. Fragment of a Letter to Frank A. Fetter, dated 22 March. FAF, Box 7, Folder: Correspondence 1924-1926.

Mayer, H., F.A. Fetter, and R. Reisch, eds. 1927-1932. Die Wirtschaftstheorie der Gegenwart. 4 vols. Vienna: Julius Springer.

McCaffrey, M. 2016. “Good Judgment, Good Luck: Frank Fetter’s Neglected Theory of Entrepreneurship." Review of Political Economy. 28 (4): 504-522.

McCraw, T.K. 2007. Prophet of Innovation: Joseph Schumpeter and Creative Destruction. Cambridge, MA: Harvard University Press.

Mises, L. von. 2008. Planning for Freedom: Let the Market System Work: A Collection of Essays and Addresses. Ed. by Bettina Bien Greaves. Indianapolis, IN: Liberty Fund.

Mises, L. von. 1998 [1949]. Human Action: A Treatise on Economics. Auburn, Al: Ludwig von Mises Institute. 
Mises, L. von. 1990. “The Disintegration of the International Division of Labor.” In, Money Method, and the Market Process. Ed. Richard M. Ebeling. Norwell, Mass: Kluwer, 113-136.

Mises, L. von. 1938. Letter to Frank A. Fetter, dated 5 February. FAF, Box 2, Folder: Correspondence 1938 Jan.-June.

Mises, L. von. 1978. "The Freedom to Move as an International Problem.” In The Clash of Group Interests and Other Essays. Ed. Richard M. Ebeling. Burlingame, CA: Center for Libertarian Studies, 19-22.

Mises, L. von. 1937. “Introduction.” In A.S.J. Baster, The Twilight of American Capitalism: An Economic Interpretation of the New Deal. London: P.S. King \& Son, v-vi.

Morgenstern, O. 1936. Letter to Frank A. Fetter, dated 13 January. FAF, Box 2, Folder: Correspondence 1936 Jan.-July.

Morgenstern, O. 1927. Letter to Frank A. Fetter, dated 10 December. FAF, Box 1, Folder: Correspondence 1927.

Mund, V. 1949. Letter to Frank A. Fetter, dated 1 March. FAF, Box 4, Folder: Correspondence 1949. O’Driscoll, G.P. 1980. “Frank A. Fetter and ‘Austrian’ Business Cycle Theory.” History of Political Economy. 12 (4): 542-557.

Robbins, L. 1971. Autobiography of an Economist. London: Macmillan.

Robbins, L. 1932. An Essay on the Nature \& Significance of Economic Science. London: Macmillan. Rothbard, M.N. 2009. Man, Economy, and State with Power and Market. Auburn, Al: Ludwig von Mises Institute. 
Rothbard, M.N. 1977. "Introduction.” In Capital, Interest, and Rent: Essays in the Theory of Distribution. Menlo Park, CA: Institute for Humane Studies, 1-23.

Salerno, J.T. 2004. “Menger's Theory of Monopoly Price in the Years of High Theory: the Contribution of Vernon A. Mund." Managerial Finance. 30 (2): 72-92.

Salerno, J.T. 1999. “The Place of Mises's Human Action in the Development of Modern Economic Thought." Quarterly Journal of Austrian Economics. 2 (1): 35-65.

Samuels, W.J., 1985. "The Resignation of Frank A. Fetter from Stanford University." History of Economics Society Bulletin, 6 (2): 16-25.

Schulak, E.-M., and H. Unterköfler. 2011. The Austrian School of Economics: A History of its Ideas, Ambassadors, and Institutions. Trans. by Arlene Oost-Zinner. Auburn, Al: The Ludwig von Mises Institute.

Schumpeter, J.A. 2018. “Schumpeter's Review of Frank A. Fetter's Principles of Economics.” Trans. by Karl-Friedrich Israel. Quarterly Journal of Austrian Economics. 21 (1): 52-59.

Schumpeter, J.A. 1954. History of Economic Analysis. New York: Oxford University Press.

Schumpeter, J.A. 1928. Letter to Frank A. Fetter, dated 30 April. FAF, Box 7, Folder: Correspondence 1927-1932.

Schumpeter, J.A. 1923. Letter to Frank A. Fetter, dated 6 March. FAF, Box 7, Folder: Correspondence 1920-1923.

Schumpeter, J.A. 1920. Letter to Frank A. Fetter, dated 7 December. FAF, Box 1, Folder: Correspondence 1920. 
Schumpeter, J.A. 1913. Letter to Frank A. Fetter, dated 4 November. FAF, Box 7, Folder:

Correspondence 1913-1914.

Schumpeter, J.A., 1908a. Das Wesen und der Hauptinhalt der theoretischen Nationalökonomie.

Leipzig: Duncker \& Humbolt.

Schumpeter, J.A. 1908b. "Einige neuere Erscheinungen auf dem Gebiete der theoretischen

‘Nationalökonomie.” Zeitschrift für Volkswirtschaft. 17: 402-420.

Schumpeter, J.A. 1908c. Letter to John Bates Clark, dated 30 December. JBC, Box 3, Folder 7.

Schumpeter, J.A. 1907a. Letter to John Bates Clark, dated May. JBC, Box 3, Folder 7.

Schumpeter, J.A. 1907b. Letter to John Bates Clark, dated 11 November. JBC, Box 3, Folder 7.

Schumpeter, J.A. Undated. Letter to Frank A. Fetter, undated (c. 1945). FAF, Box 4, Folder:

Overhead Costs.

Stearns, P. 1921a. Letter to Frank A. Fetter, dated 17 February. FAF, Box 1, Folder: Correspondence 1921.

Stearns, P. 1921b. Letter to Frank A. Fetter, dated 24 March. FAF, Box 1, Folder: Correspondence 1921.

Wasserman, J. 2016. “'Un-Austrian’ Austrians? Haberler, Machlup, and Morgenstern, and the PostEmigration Elaboration of Austrian Economics." Research in the History of Economic Thought and Methodology. 34: 93-124.

Whitaker, A.C. 1916. “Fetter's Principles of Economics.” Political Science Quarterly. 31 (3): 430444. 